\title{
Growth and Prospect of Islamic Finance in Bangladesh
}

\author{
Md. Moniruzzaman ${ }^{1}$ \\ 1 Senior Lecturer (Finance), Department of Business Administration, Stamford University Bangladesh, \\ Bangladesh \\ Correspondence: Md. Moniruzzaman, Senior Lecturer (Finance), Department of Business Administration, \\ Stamford University Bangladesh, Bangladesh. Mailing Address: 51, Siddeswari, Dhaka-1217. Room \# A-215. Tel: \\ 88-01924-032-434. E-mail: mzaman.sub@gmail.com
}

Received: March 15, 2018; Accepted: April 9, 2018; Published: June 30, 2018

\begin{abstract}
Though conventional financial system is contributing swiftly to the economic development but the Islamic finance is not lacking behind of it now a days. The Islamic finance industry has emerged as one of the component of a rapid economic growth over the past three decades. Initially the activities of Islamic finance is limited within the country, but at present the growth of Islamic finance are thought globally with an upward trend through the establishment of various Islamic financial institutions with different shareholders. This paper examines insights into the growth and prospect of Islamic finance in Bangladesh. Islamic finance is ruled by Islamic Finance Guidelines which is issued and approved by Central Bank of Bangladesh. This system has its own principles and guidelines which would make the system of choice in meeting specific investment needs. It compares Islamic and conventional finance regard to Efficiency and Profitability, Risk Management, and Sukuk and Conventional Bonds. In Bangladesh, the atmosphere is exclusive because of the existence of Islamic banking sector. But the country has some deficiencies in imposing specific Islamic finance regulations which have been recognized and efforts are being made to solve the problems by the authorities.
\end{abstract}

\section{JEL Code: E58, F65, G21, G28}

Keyword: Islamic finance, growth, prospect, Bangladesh

\section{Introduction}

Islamic Finance is ruled by the Shariah (Islamic Law). It is obtained from the holy Quran and the Sunnah, which are followed by the consensus of the jurists and interpreters of Islamic law. The Islamic mode of finance should emphasize profit and loss sharing and prohibit interest according to Shariah. From the Islamic point of view, any fixed payment above the actual amount of the principal (i.e. interest) is illegal. Uncertainty, risk and speculation related activities are banned by the the Shariah. Investment those businesses which are dealing with alcohol, drugs and gambling, and also considered unlawful or undesirable also included in this prohibition (Grail, 2007). Islamic financial system should be followed by Islamic rules and regulations, not for the name and label only, but also it must maintain the philosophy, values, ethics and objectives of Islamic Shariah.

In Bangladesh, the growth of the Islamic finance industry has been recognized through the originations of the international financial services industry. The regular development of the Islamic finance industry is modest retail offerings, sophisticated corporate banking products, pioneering project finance solutions and commercial banking.

Islamic finance has started its journey with simple banking solutions that encourage savings and financing in 1970. The products were designed with Shariah principles and guidelines and easily understood by the public. In 1980, new financial products such as project finance and syndications were inaugurated. After 10 years, Ijarah and equity were included. Finally in 2000, sukuk, formed and alternative assets, liquidity and management tools also were implemented.

Now a days, the growth and potentiality of Islamic finance is dynamic and it is considered as a competitive substitute of conventional financing solutions in Bangladesh. There are so many diverse local and foreign players are available in the market, who are constantly showing their dynamism with a wide array of innovative financial products and services. Islamic banking is comprised of $30 \%$ of the total banking sector. So it can be said that there is a huge potentiality and scope of practicing Islamic finance in Bangladesh. 


\section{Principles and Products of Islamic Finance}

The basic principles of Islamic finance include profit and risk sharing and it is free from interest. It also adds transparency and full disclosure, good governance, value-based innovation and principles of justice. The dominant principles regarding Islamic finance are the following:

1. Any fixed or predetermined payment above the principal amount is prohibited.

2. Islamic finance entails that all banking business based on sale or lease must have an underlying asset.

3. Profit and loss sharing concept. Investors must receive the profit and obey the loss as well.

4. Interest is the money for the use of the money and which is prohibited by Islamic law. Money is considered only as a medium of exchange. If anyone lends money to someone and the borrower provides more than the money he/ she borrows at the time of payment or if anyone saves money at the bank and after a period bank provides more than it receives is strictly prohibited in the eye of Islamic law.

5. Gharar (uncertainty, risk or speculation) is also banned.

6. Investments should be done only on halal products which are supported by Islam.

7. Islamic finance is based on Shari'ah compliance. A distinctive characteristics of Islamic finance is to establish a Shari'ah advisory or supervisory board to ensure compliance so that it can advise IFIs, Islamic insurance companies, Islamic funds and any other providers which offer Islamic financial products.

A brief description of Islamic financial products is given below: (Imady and Seibel, 2006) (Grail, 2007)

\section{i) Profit sharing financial products}

- Musharakah-Under Musharakah, all the partners share the capital and participate in the management decision making process of the business. Profits are distributed in an agreed ratio but losses are distributed in the ratio of capital invested. Contributions can be done either in cash or in kind. It is like joint venture business.

- Mudarabah-Mudarabah is a special kind of partnership where one partner provides the full capital to the other party for investment in a commercial enterprise. It can be classified into 3 categories. The categories are asset based, liability based and profit sharing. The person who is providing capital is called raab-ul-maal and another person is called mudarib. Here, profits are distributed in a pre-agreed ratio whereas losses accrued are borne by the raab- ul-maal only. The management is operated by the mudarib only.

- Qard Hasan-It is a charitable loan which is free from interest and maintain profit- sharing margins. Repayments are possible through installments. The service charge is moderate.

- Wakalah- In terms of Wakalah, on behalf of customer a bank is assigned to conduct the business.

- Hawalah- A bank made an agreement with the customers to accept some of the liabilities of the customer in return for a service fee. The customer pays back the bank when the liabilities paid.

\section{ii) Advance purchase financial products}

- Murabahah- It is two types- asset based and cost plus financing. The commodity is bought and sold by the bank. The bank sells the commodity at higher price than the purchasing price to the capital user. The bank also discloses the margin of profit. The customer can use deferred payment or installment method. If the customer uses deferred payment he/she is liable only for the contracted selling price.

- Istithna'- It can be classified as asset based and commissioned manufacturing. According to the Istithna', a bank takes the responsibility to manufacture a particular item according to the specifications of the customer at a determined price and deliver the item at the fixed date. A parallel contract is formed for manufacturing because the bank is not directly involved in manufacturing the items. The bank pays to the manufacturer for manufacturing the items. The bank receives the price from the customers including the manufacturing fees and reasonable profit (monetary installment) and the risk of manufacture of the items.

- Mu'ajjal-Mu'ajjal is a type of Islamic finance credit sale that is compliant with the shariah. Mu'ajjal literally means credit sale. In a Bai Mu'ajjal the financial institution will earn a profit margin on the price of a purchased asset or assets and will let the buyer pay off the price and they can do so all at once or in installments. Both the parties in this Islamic finance transaction must agree upon the cost of the asset, as well as the profit margin. Bai Mu'ajjal is also referred to as a deferred payment sale.

- Ijarah-Generally, it means to give something on rent. In the Islamic point of view, the term Ijarah is used for two different situations. In the first place, it means to employ the services of a person on wages given to him or 
her as a consideration for his or her services. The employer is called mustajir and the employee is called the ajir. The second type of Ijarah relates to leasing.

- Tawarruq- It can be classified as asset based and monetization of commodity. It is developed by banks. Here, the banks lend cash to customers and the customers purchase a goods from the bank under Murabahah which is then sold to a third person on cash at a price less than the purchase price. The customer hence obtains interest free loan easily. If the commodity is sold by the customers to the bank, this is called Al-'inah.

iii) Deposit products

- Kadijah- Current account deposits (giro wadi'ah).

-Mudarabah-It is a deposit product between customer and bank, such as savings account products where amount can be withdrawn and deposit any time.

- Qard al-Hasanah-Basically it is used for charitable purposes. It is a voluntary deposits.

\section{iv) Insurance products}

- Takaful-It is an Islamic insurance. Takaful is originated through mutual co-operation, responsibility, protection and assistance between insurers and insure. It works as a cooperative insurance wherein members contribute a specific sum of money to a common pool. Every policyholder tries to help the poor people by paying the premium. Losses and liabilities are scattered based on community pooling system.

\section{iv) Sukuk}

It is an Islamic bond. Sukuks are same as conventional bonds the main differences are bonds are asset backed and represent proportionate beneficial ownership in the underlying asset.

All are Shariah-based products, like Sukuk, Takaful, Khadijah, Tawarruq, Muajjalal, Ijarah and so on. So it can be proved that, successful Islamic financial services is considered as one of the fastest growing services in the financial services industry in Bangladesh.

\section{Islamic Finance in Bangladesh}

As Bangladesh is the third-largest Muslim country in the world with a population of 160 million Muslims forecasted at year- end 2016, it is a center for practicing and applying Islamic finance. The popularity of Islamic finance is growing at a rapid pace in Bangladesh. The first Islamic Bank, IBBL was established in 1983. After that a good number of Islamic banks has grown steadily. Now Islamic banking industry is well -established, with $21.1 \%$ of market share, and plays a vital role in the country's rapid economic growth. Many conventional banks are now moving to Islamic principles from traditional principles. Even at least, they are trying to launch a one Islamic banking branch to fulfill the customer demand.

Table 1. Structure of the Banking System of Bangladesh (December, 2016)

\begin{tabular}{|c|c|c|c|c|}
\hline Types of Bank & $\begin{array}{l}\text { No of } \\
\text { banks }\end{array}$ & $\begin{array}{l}\text { No. of } \\
\text { branches }\end{array}$ & $\begin{array}{l}\text { Total asset } \\
\text { (billion Tk) }\end{array}$ & $\begin{array}{l}\text { Percentage of } \\
\text { assets }(\%)\end{array}$ \\
\hline SCB State-owned commercial banks & 06 & 3710 & 3209.5 & 27.6 \\
\hline $\begin{array}{l}\text { DFI State-owned development } \\
\text { financial institutions }\end{array}$ & 02 & 1407 & 299.5 & 2.6 \\
\hline $\begin{array}{l}\text { PCB Private commercial banks } \\
\text { of which only } \\
\text { conventional }\end{array}$ & $\begin{array}{l}40 \\
10\end{array}$ & 4467 & 7560.0 & 65.0 \\
\hline $\begin{array}{l}\text { of which only Islamic } \\
\text { of which Islamic } \\
\text { and conventional }\end{array}$ & $\begin{array}{l}10 \\
20\end{array}$ & & & \\
\hline $\begin{array}{l}\text { FCBs(Foreign commercial banks) } \\
\text { of which only conventional } \\
\text { of which Islamic and conventional }\end{array}$ & $\begin{array}{l}\mathbf{0 9} \\
03 \\
06\end{array}$ & 70 & 557.6 & 4.8 \\
\hline Total & 57 & 9654 & 11626.6 & 100 \\
\hline
\end{tabular}

Source: Bangladesh bank annual report, 2016-2017 
Private commercial banks and foreign commercial banks contain $69.8 \%$ of the total banking assets. Three-fourth of the domestic private commercial banks ( 30 of 40) and one-third of the foreign commercial banks ( 3 of 9) offer Islamic financial services, either as stand-alone Islamic banks or as conventional banks in Islamic branches. The state-owned scheduled banks (except Janata Bank, under processing) did not still offer Islamic financial services to their valued clients. It can be the one reason for dropping down their market share and customer retention.

The total number of Islamic Banking branches (including Islamic branches of conventional banks and windows) stood at 1051 at the end of 2016 which was 1042 in 2015 . There are 8 full-fledged Islamic banks with 1006 branches, 9 conventional banks with 20 Islamic banking branches and 8 conventional banks with 25 Islamic banking windows in 2016. Islamic banking branches capture $11.05 \%$ market share among all scheduled banks. Information on branches of Islamic banks is shown in Table 2.

Table 2. Number of Bank Branches of Islamic Banks (2016)

\begin{tabular}{lllll}
\hline & Name of the Bank & Urban & Rural* & Total \\
\hline A) & Full-fledged Islamic Banks & $\mathbf{6 1 2}$ & $\mathbf{3 9 4}$ & $\mathbf{1 0 0 6}$ \\
$1 \mid$ & Islami Bank Bangladesh Limited* & 217 & 87 & 304 \\
$2 \mid$ & ICB Islamic Bank Limited & 28 & 5 & 33 \\
$3 \mid$ & Social Islami Bank Limited* & 65 & 56 & 121 \\
$4 \mid$ & Al-Arafah Islami Bank Limited & 72 & 65 & 137 \\
$5 \mid$ & EXIM Bank Limited & 62 & 48 & 110 \\
$6 \mid$ & Shahjalal Islami Bank Limited & 60 & 34 & 94 \\
$7 \mid$ & First Security Islami Bank Limited & 80 & 73 & 153 \\
$8 \mid$ & Union Bank Limited & 28 & 26 & 54 \\
B) & Islamic banking branches of Conventional banks & $\mathbf{1 7}$ & $\mathbf{3}$ & $\mathbf{2 0}$ \\
$1 \mid$ & The City bank Limited & 1 & 0 & 1 \\
$2 \mid$ & AB Bank Limited & 1 & 0 & 1 \\
$3 \mid$ & Dhaka Bank Limited & 2 & 0 & 2 \\
$4 \mid$ & Premier Bank Limited & 1 & 2 & 3 \\
$5 \mid$ & Prime Bank Limited & 5 & 0 & 5 \\
$6 \mid$ & Southeast Bank Limited & 4 & 1 & 5 \\
$7 \mid$ & Jamuna Bank Limited & 2 & 0 & 2 \\
$8 \mid$ & Bank Alfalah Limited & 1 & 0 & 1 \\
$9 \mid$ & HSBC Limited & 0 & 0 & 0 \\
C) & Islamic banking windows of Conventional banks & 25 & $\mathbf{0}$ & $\mathbf{2 5}$ \\
$1 \mid$ & Sonali Bank Limited & 5 & 0 & 5 \\
$2 \mid$ & Janata Bank Limited** & 0 & 0 & 0 \\
$3 \mid$ & Agrani Bank Limited & 5 & 0 & 5 \\
$4 \mid$ & Pubali Bank Limited & 2 & 0 & 2 \\
$5 \mid$ & Trust Bank Limited & 5 & 0 & 5 \\
$6 \mid$ & Standard Bank Limited & 2 & 0 & 2 \\
$7 \mid$ & Bank Asia Limited & 5 & 0 & 5 \\
$8 \mid$ & Standard Chartered Bank & 1 & 0 & 1 \\
D) & Total=A+B+C & $\mathbf{6 5 4}$ & $\mathbf{3 9 7}$ & $\mathbf{1 0 5 1}$ \\
\hline
\end{tabular}

* Including SME **Janata Bank Limited has obtained permission for starting Islamic Banking window from Bangladesh Bank, but not yet started.

The Capital Adequacy Ratio (CAR) of Islamic banking industry is higher and it disburses lower non-performing loans than conventional banks which is a good sign for Islamic finance industry. It has also faster financing growth compare to conventional banking. The deposits, investments, investment- deposit ratio and the surplus liquidity of Islamic banking industry grew by $1.46 \%, 1.42 \%, 0.34 \%$ and $7.56 \%$ respectively at the end of 2016 , while remittances collection reduced by $3.21 \%$ compared to the previous year. Among the entire banking industry, Islamic Banking Industry hold more than one-fifth share in terms of deposits and investments at the end of 2016 under review. 
Table 3. Highlights on Islamic Banking Sector in Bangladesh (December, 2016)

\begin{tabular}{lllll}
\hline Particulars & 2016 Amount (Tk.) crores & $\begin{array}{l}\text { 2015 Amount } \\
\text { (Tk.) crores }\end{array}$ & Changes & $\begin{array}{l}\text { Increase/ Decrease } \\
\text { (\%) }\end{array}$ \\
\hline Total Deposit & Tk. 178137.17 & 175563.27 & 2573.9 & 1.46 \\
Total Investment & Tk. 158849.69 & 156623.94 & 2225.75 & 1.42 \\
Investment-Deposit Ratio & 0.89 & 0.86 & 0.03 & 0.34 \\
Surplus Liquidity & Tk. 11401.30 & 10599.26 & 802.04 & 7.56 \\
Total Remittances & Tk. 9378.59 & 9689.89 & $(311.3)$ & $(3.21)$ \\
The Number of Branches & 1051 & 1042 & 9 & 0.0086 \\
Total Manpower & $\mathbf{2 8 8 8 9}$ & $\mathbf{2 8 8 4 4}$ & $\mathbf{4 5}$ & $\mathbf{0 . 0 0 1 5}$ \\
\hline
\end{tabular}

Source: Bangladesh bank annual report, 2015-2016

The Islamic banking industry is guided and controlled by the central bank of Bangladesh. The Securities and Exchange Commission (SEC) has full regulatory authority for monitoring capital market performance, and the Insurance Development \& Regulatory Authority Bangladesh oversees the insurance and Takaful sectors.
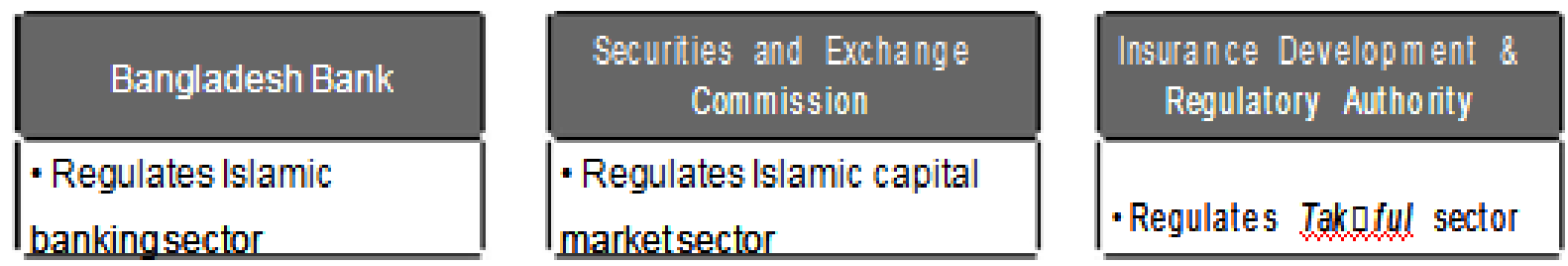

Figure 1. Financial Regulatory Bodies in Bangladesh

There is no specific Islamic banking act for controlling, guiding and supervising the activities of Islamic banks in Bangladesh. Now some Islamic banking provisions is being incorporated in the amended of Banking Companies Act 1991 (Act No. 14 of 1991). Bangladesh Bank oversees and monitors Islamic banks' operations according to the regulations set down for conventional banks. The Shari ah councils of individual banks are ensuring Shari ah compliance within their own organizations, and they send a report to Bangladesh Bank. BB examines the reports according to the guidelines. If ay discrepancies found, notify the respective banks.

In Bangladesh, the Islamic finance industry is encompassed with talented banking and Takaful segment including a number of active players which are serving to the domestic markets as well. Bangladesh Bank has already taken some superior initiatives for the swift growth of the Islamic banking industry which can bring the smooth development of Islamic banking in Bangladesh. The initiatives are following:

$>$ In Bangladesh, the Statutory Liquidity Requirement (SLR) should be maintained 20\% for conventional banks. But Bangladesh Bank allows 10\% SLR for Islamic banks in Bangladesh of their total deposit liabilities. It enables Islamic banks to use more liquid funds for investment. Thus more profits can be generated.

$>$ Islamic banks have been allowed to set their profit-sharing ratios and mark-ups by their own, according to their own policy and banking rules under the indirect monetary policy regime. Islamic banks can follow the principles of Sharia's law independently using the opportunity.

> Islamic banks have been permitted to repay $10 \%$ of their proportionate administrative cost on a part of their balances held with Bangladesh Bank. This scope can maximize of a bank's profit.

The government of Bangladesh should concentrate on the Islamic capital market and instruments such as Sukuk for the fastest growth of Islamic finance industry in Bangladesh, which have proven to be a vital fund-raising tool for corporations and governments throughout the world. The Bangladesh government is planning to introduce Sukuk which is considered as an instrument for financing at Islamic banks.

There are many areas and scopes in Bangladesh for the significant growth of Islamic finance industry, particularly in the capital market arena such as introducing sukuk. Most of the citizen in Bangladesh are illiterate. They don't have any knowledge regarding this issue. So, the Islamic finance industry is not growing at an increasing rate in spite of having huge potentialities in Bangladesh. 


\section{Global Overview: Issues, Challenges and Opportunities}

In 1963, in Egypt, the Islamic finance industry has come at the stage of a viable, resilient and suitable alternative in the global financial landscape. Mainly, the finance industry began as a niche market in retail banking. It has been operating in 75 countries now with 600 institutions offering various Shairah based financial products like takaful (insurance), mutual funds and capital market products. It is not only practiced in the Muslim majority countries, but it is also growing fast in non-Muslim countries and attracting swiftly both Muslim and non-Muslim. The conventional financial industry faced severe confusion during the global financial crisis between 2007-2008. At that time, the Islamic finance industry showed much elasticity compared to their conventional counterparts. Policy makers became more enthusiastic around the world as Islamic finance has achieved the ability to bring financial stability.

The Islamic finance industry has experience for bringing the exceptional progress in terms of geographical converge, offering diversified Islamic financial services and exponential growth. The total assets of global Islamic finance industry are estimated to be worth USD 1.87 trillion in 2014 from USD 1.50 billion in mid-1990s. Banking, sukuk, mutual funds, and takaful are included in the global Islamic finance industry with a compound annual growth rate (CAGR) of 17\% between 2009 and 2013. The status of global Islamic financial industry is depicted in Table 4. (USD Billion)

Table 4. Geographical Distribution of Islamic Finance Segments (2016)

\begin{tabular}{llllll}
\hline Region & $\begin{array}{l}\text { Islamic } \\
\text { Banking }\end{array}$ & $\begin{array}{l}\text { Sukuk } \\
\text { outstanding }\end{array}$ & $\begin{array}{l}\text { Islamic Funds } \\
\text { Assets }\end{array}$ & $\begin{array}{l}\text { Takaful } \\
\text { Contributions }\end{array}$ & Total \\
\hline Asia & 218.6 & 182.7 & 19.8 & 4.4 & 425.5 \\
GCC & 650.8 & 115.2 & 23.4 & 11.7 & 801.1 \\
MENA (ec-GCC) & 540.5 & 16.6 & 0.2 & 8.4 & 565.7 \\
Africa (ex-North Africa) & 26.5 & 1.9 & 1.5 & 0.6 & 30.6 \\
Others & 56.9 & 2.1 & 11.2 & - & 70.2 \\
Total & $\mathbf{1 4 9 3 . 4 0}$ & $\mathbf{3 1 8 . 5}$ & $\mathbf{5 6 . 1}$ & $\mathbf{2 5 . 1}$ & $\mathbf{1 8 9 3 . 1 0}$ \\
\hline
\end{tabular}

Source: Islamic Financial Services Industry Stability Report 2017, IFSB, Malaysia.

The global Islamic financial industry has been dominated by the Islamic banking sector with higher concentration in the MENA, GCC and Asian regions. They have larger Muslim population and vibrant emerging economies, relied petro dollar.

Islamic capital market named Sukuk continued to outpace most other asset classes in the global financial system. Sukuk is broadly used by both government and corporate sectors which is an important vehicle for international fund-raising and investment activities that generate significant cross-border flows. Now, there are four major global Islamic guides providers which cover the Islamic equity market such as Dow Jones Islamic Market Indices, Standard and Poor Shariah Indices, MSCI global Islamic Indices and FTSE global Islamic Guides. Sukuk primary market is very popular in Malaysia, Qatar, the UAE, Saudi Arabia and Indonesia now a days. The sukuk assets are also available in the secondary market with a high growth rate.

Islamic funds under asset management grew to USD 75.8 billion from USD 29.2 billion in 2004, representing a CAGR of $10.8 \%$. The takaful industry has reached double-digit growth rates figure despite of having small market in recent years. The industry's contribution is to be estimated at USD 21.4 billion in 2014 with an average annual growth of $15 \%$ between $2008-13$ periods.

\subsection{Shares of Islamic Banking Market in Muslim Majority Countries}

The Middle East, South-East Asia and South Asia Muslim majority countries are considered as the leading Islamic financial Industry centers, although almost all 56 nations OIC countries have introduced Islamic finance. Iran and Sudan have fully implemented Shariah-based financial systems in their country. Islamic banking market share of total banking industry in Kuwait is above $60 \%$ followed by Saudi Arabia (33\%), Qatar, UAE, Malaysia and Bangladesh (30\%) and Syria, Bahrain, Yemen and Jordan(10\%) among other major Muslim countries based on the data in 2016. Egypt, Turkey, Pakistan and Indonesia have below 10\% Islamic banking market share. List of Muslim majority countries having Islamic finance is shown in Table-05. 
Table 5. Major Muslim countries offering Islamic Finance

\begin{tabular}{ll}
\hline Name of the regions & Name of the Countries \\
\hline Middle East & $\begin{array}{l}\text { Iran, Iraq, Kuwait, Saudi Arabia, Qatar, UAE, Bahrain, Oman, Lebanon, } \\
\text { Jordan, Syria, Yemen, Turkey }\end{array}$ \\
South East Asia & Malaysia, Indonesia, Brunei \\
South Asia & Bangladesh, Pakistan, Afghanistan, Maldives \\
Middle Asia/ Europe & Azerbaijan, Uzbekistan, Tajikistan, Kazakhstan, Albania, Cyprus \\
Africa & Sudan, Egypt, Libya, Nigeria, Tunisia, Morocco, Algeria, Senegal, \\
& Gambia, Djibouti, Niger, Guinea, Mauritania, Mali
\end{tabular}

Source: IFSB, MIFC and Islamic Finance Development Report 2017, ICD Thomson Reuters

In terms of share of Global Islamic Banking, Iran is the top among all Muslim majority countries Assets securing $39.70 \%$ assets followed by Saudia Arabia (13.70\%), Malaysia (9.80\%), UAE (9.10\%) and Kuwait (9.0\%).

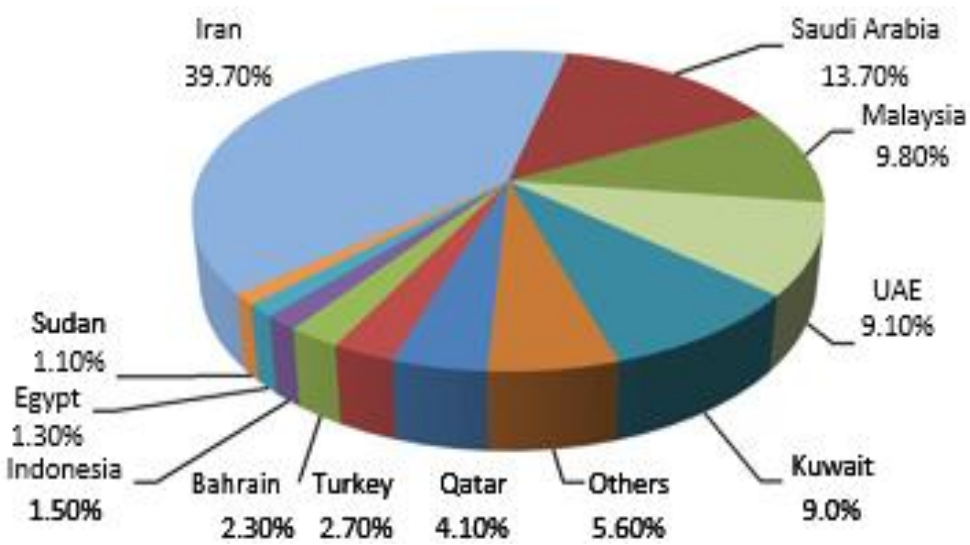

Figure 2. Country Share of Global Islamic Banking Assets (2016)

Source: Islamic Financial Services Industry Stability Report 2017, IFSB, Malaysia.

\subsection{Developments of Islamic Finance in Western Countries and other Regions}

Considering the religious factors the people of Muslim country are not only adopting the islamic finance, but also the non-Muslim people of the western world and other jurisdiction have started to avail Islamic financial services motivated by commercial considerations. If people follow the Islamic jurisdiction, they can earn more profit and it brings happiness in their mind as well. So the growth of Islamic finance is very certain globally using this philosophy. These countries have already started in taking different policies and trying to bring changes in their legal and tax structure to facilitate the Islamic financial products into their markets.

Among the western world, The United Kingdom (UK) is the top country in using Islamic financial products. The west's first fully fledged Shari'ah-based retail bank was established in UK and at present, it has five Islamic banks. Like UK, other western countries such as France, Germany, Italy, Ireland, Luxemburg, Switzerland and USA are providing Islamic financial services among their clients (Di Mauro, F et. al. 2013). China, Hong Kong and Singapore which are surrounded in Asia are also increasingly offering Islamic financial services to their retail and corporate customers. Russia, Japan and India have also shown greater interest in Islamic finance (MIFC 2016).

Table 6. Major Non-Muslim Countries offering Islamic Finance

\begin{tabular}{ll}
\hline Name of the regions & Name of the Countries \\
\hline Europe & UK, France, Germany, Italy, Ireland, Luxemburg, Switzerland, Denmark, Belgium, \\
& Russia \\
Asia & China, Hong Kong, Singapore, Thailand, Philippines, Japan, India, Sri Lanka \\
Africa & South Africa, Kenya \\
America & USA, Canada \\
Australia & Australia, New Zealand \\
\hline
\end{tabular}

Source: IFSB, ECB, MIFC and Islamic Finance Development Report 2013, ICD Thomson Reuters 
The global Islamic finance industry has entered into its fifth decade of existence in its modern re-emergence. Now a days it is considered as one of the vital industries in establishing the financial stability, though it constitutes only $1 \%$ of the total global financial assets. In 2005, the net worth of the industry was approximately USD700 billion, but at the end 2012, its value had doubled to USD1.6 trillion. It is expected that the total Islamic financial assets will have a value of USD 6.5 trillion at an estimated compounded annual growth rate (CAGR) of $19.15 \%$ by 2020 .

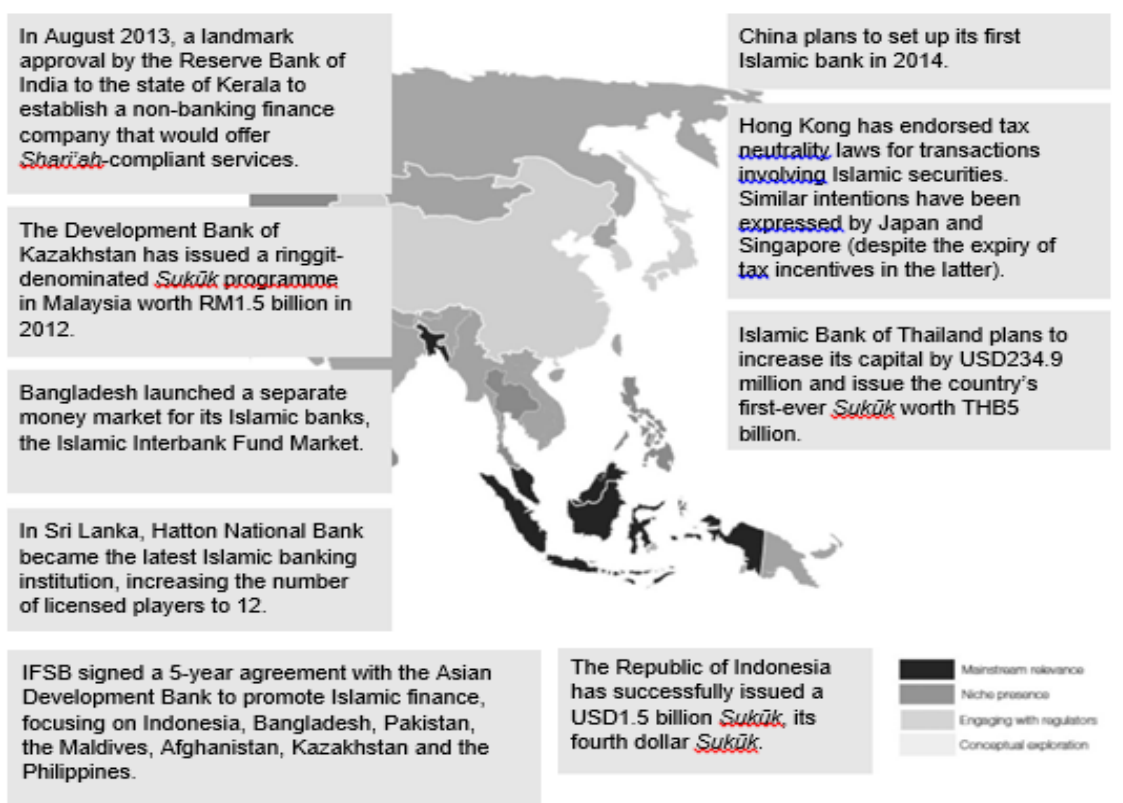

Figure 3. Islamic Financial Markets Developments in Asia (2015-2016)

Source: KFHR

Asia creates the linkage between the global economy and the Islamic financial system which bring the economic growth. Quick global economic expansion is possible after the growth of Islamic finance in this region. However, more concentration is needed to facilitate an enabling environment that supports smooth functioning of the Islamic finance industry, as well as to advance developed Islamic financial markets to the next level. An enabling legal and regulatory framework, a competent talent pool, and greater product innovation and awareness are among key areas for improvement.

\section{Comparison between Islamic and Conventional Finance}

\subsection{Efficiency and Profitability}

The effectiveness of Islamic banks is compared with conventional banks. Before the global recession, it has been found that in most of the research that the efficiency of both banking system was not significantly different. The story has been changed after the global recession. It has been found in the recent studies that the profitability of Islamic banks have been decreased more than for conventional banks in certain years. Because the lower risk management practice and financial crisis of Islamic banks. But the international evidence recommends that the cost and profit ratio of Islamic banks are rising. For this reason, Islamic banks in forwarding countries seem to be more efficient than those in other countries.

\subsection{Risk Management}

Islamic banks also face some unique risks like conventional banks. The Shari'ah distinguishes them from conventional banks while at the same time exposing them to similar market, credit, liquidity, operational, and legal risks. Islamic financing is also subject to high judicial risk. When Islamic banks enter into musharakah and mudârabah partnerships, the equity risks start as they are the providers of funds and also share in the business risk of the activity. Mark-up risk is high for Islamic banks. According to The Islamic Development Bank (IDB), Islamic banks face more severe mark-up (interest rate) risk in fixed-income instruments like istisna' and murahabah in 2001. Islamic financial institutions can get more benefits through the standardization of Shari'ah compliance. Unlike conventional banking where a unified set of international standards help agents to identify risks associated with the bank's activities, Islamic financial institutions often face difficulties presenting internationally accepted Islamic instruments to their customers. 


\subsection{Sukuk and Conventional Bonds}

The asset-based financial securities is Sukuk. According to AAOIFI, sukuk are certificates of equal value representing undivided shares in ownership of tangible assets, property right, and services. Sukuk are not considered as debt certificates with a financial claim to cash flow, and for pooling receivables sukuk are not issued. Rather, they are same as an ownership certificate with proportional or undivided interest in a project or an asset, and carrying the right to a proportionate share of cash flows. The unique feature of sukuk is underlying asset. The price of sukuk is varied based on the market value of the asset or project being financed. Sukuk investors are asked for asset-related expenses. Moreover, the bond holders can sue against the borrower if the borrower default, but for sukuk contracts, automatic transfer of ownership is possible in case of default on payments.

\section{Growth Areas of Islamic Finance in Bangladesh}

In Bangladesh, lower-income groups and small to moderate-sized businesses are available and this group prefer microcredit. So undoubtedly there is a huge potentiality of Islamic finance in Bangladesh. Grameen Bank is the pioneer of microfinance in Bangladesh in 1976. Bangladesh is considered as one of the Muslim country in establishing Islamic microfinance with more than 100,000 clientele. Islami Bank Bangladesh Limited (IBBL), the largest Islamic bank in Bangladesh is also the largest provider of Islamic micro financing. IBBL took first initiative of Islamic microfinance program in 1995 named the Rural Development Scheme (RDS). The main objective of this scheme is to eliminate rural poverty through small and microcredit products or schemes. The total disbursement of IBBL is USD504.9 million in micro finance program since 1995

IBBL initiatives are not only limited by its microcredit activities, the bank has discovered several ways to further broaden its activities to a large number of lower-income groups and small to moderate businesses. The Initiatives can be different deposit accounts with small amounts especially for the students and farmers; welfare deposit schemes for cash Waqf and hajj; small saving schemes for the women empowerment;

Islamic microcredit is supported by the Islamic finance. The lower income group can lead a better and prosperous life through the activation of the microcredit and thus economic as well as religious growth and prosperity can be possible. The Islamic microfinance sector may receive the challenge to prove itself as a successful financing tool so that it can be applied to other regions around the world.

In Bangladesh, Islamic banking sector has been able to capture a significant portion of the overall banking system despite the lack of a regulatory framework for Islamic finance. Now Bangladesh is regarded one of the top five jurisdictions in the world in terms of market penetration, and it is a remarkable achievement for a country. Again it has been proved that there is a huge potentiality of Islamic finance in Bangladesh. Most of the people in Bangladesh are Muslim. They want to establish Islamic finance. If the adaptation of Islamic finance is successful, other banks and institutions which follow conventional rules will shift to Islamic finance to retain their market share.

\section{Challenges and Policy Options of Islamic Finance in Bangladesh}

The challenges are given below:

i) Absence of Separate law: There is no separate law for implementing Islamic finance in Bangladesh. Bangladesh Bank monitors and supervises Islamic banks based on some clauses incorporated in the Bank Company Act, 1991 (last amended in 2013) which is used to monitor and supervise interest based traditional banks. Besides, the profit and loss sharing (PLS) principles of Islamic finance do not come fully under the jurisdiction of the existing civil laws. As a result, if any disputes arises in regulating Islamic finance in Bangladesh, it is very difficult to handle for civil law.

ii) Shortage of Islamic money market instruments: An active money market plays an important role in liquidity management of banks through short term tradable financial instruments. In Bangladesh, there are restricted sources of Shari'ah compliant funds. Islamic principles following firms can obtain funds either from the Islamic inter-bank money market, or from the "Islamic Investment Bond's Fund" which is issued by the Bangladesh Government. The shortage of sufficient interest free securities is one of the major obstacles of liquidity management.

iii) Prevalence of Murabaha, Bai-muajjal and Ijara financing: Murabaha, Bai-muajjal and Ijara are considered as marked up and rental based investment modes in Islamic Finance. The Islamic finance is heavily relied on these modes which accounts for above $90 \%$ of total investment. But in Bangladesh, Islamic banks and other Islamic institutions cover only small portion of these investment modes as these modes are followed by profit and loss sharing principles. 
iv) Small Share of Financing in social sectors: A research reveals that Islamic finance industry in Bangladesh is dominated by the large projects or firms and the research is conducted by the Islamic banking industry in Bangladesh. Micro and SME sector do not get fair priority.

v) Absence of Role in Government Project Financing: The Government of Bangladesh borrows huge amount of funds from conventional banks through issuing treasury bills and bonds every year for ensuring the rapid economic growth. Thus more employment opportunity is created. Islamic banks and other Islamic institutions also participate in this lending program to Bangladesh Government. As they are following profit and loss sharing principles, they cannot participate in public projects as lender.

vi) Lack of Number of Islamic Insurance companies: Without the assistance of Islamic insurance companies (takaful) the smooth development of Islamic finance is not possible. In Bangladesh, only three general takaful companies exist which are not enough to protect investments against unforeseen hazards for Islamic finance. Islamic institutions have to rely on interest based insurance companies in most of the cases.

vii) Inadequate of Skilled Human Resources: There is not sufficient skilled human resources which have a clear understanding of Shariah based financial services in Bangladesh. But in terms of conventional banks, there are available skilled human resources having a good understanding of interest based banking. So, from this perspective Islamic based organizations are lacking behind in Bangladesh.

viii) Few opportunity of Islamic Financial Literacy program: Many people, even old clients are not familiar with Shariah based Islamic products despite the growth of Islamic finance over the last 30 years. This is possible because of the absenteeism of Islamic financial literacy program in Bangladesh. The clients have no knowledge regarding shariah based banking.

Policy implications: The policy implications are in the following

i. Introducing Standard and Appropriate Legal Framework: There are some clear differences between conventional and Islamic financial industry on the basis products and legal contracts. Besides, Islamic financial industry should give concentration on Shariah aspects in financial operations. The Development of proper legal framework is necessary for monitoring, guiding and supervising Islamic Banking to bring sustainability in the entire Islamic finance Industry in Bangladesh.

ii. Maintaining International Standards: Islamic finance companies must maintain international regulatory standards set by AAOIFI and IFSB to remove ambiguity. It is also necessary to formulate and implement unified mode of Fund Raising and Investments.

iii. Rapid Development of other Segments of Islamic finance: Islamic finance cannot flourish as a complete industry without proper development of Micro Finance Institutes, Takaful and Islamic Capital Markets, capable to serve different segments of the people of the country. Regarding this matter MRA, IDRA and BSEC should come forward to undertake necessary steps for smooth development of Islamic Micro Finance Institutes, Takaful and Islamic Capital Markets.

iv. Promoting Investment under Musharaka and Mudaraba mode of Investment: Bangladesh Bank may provide necessary directions to Islamic banks and Islamic branches/windows of conventional bank for investing at least $10 \%$ of investable funds since investments made by Islamic banks are too low (below $2 \%$ ) in Musharaka and Mudaraba, which is considered as the ideal Islamic modes.

v. Increasing Investment in Agriculture and Social Sectors: One of the key objectives of Islamic finance is to ensure welfare of the mass people. Islamic firms or banks should invest much (now below 2\%, industry average 5\%) in agriculture, and other social sectors like poverty alleviation, education, skill developments and health sectors. The wings of the banks and firms are scattered into rural area so that the people can be benefited.

vi. Establishment of Supporting and Complementary Institutions: It is necessary to undertake some steps for establishing adequate number of supporting and complementary Institutions of Islamic Finance Industry. These institutes can be accounting and auditing firms, credit rating agency and investment broker's houses.

vii. Necessary Supports for Islamic Bank Branches/Windows of Conventional Banks: For the betterment of Islamic finance, Bangladesh Bank should pay special attention to remove the blockages of Islamic Bank Branches/Windows of Conventional Banks. 
viii. Establishment of Separate 'Islamic Finance Department' at Bangladesh Bank: For the formulation and implementation of policies for all the Islamic Banks and Islamic Bank Branches/windows of Conventional Banks a separate 'Islamic finance Department' should be established at Bangladesh Bank.

ix. A Strong Islamic Finance Research Unit under Research Department: Most of the problems in establishing Islamic finance can be solved with more research and dedicated efforts. Research can be done relating to Islamic finance issue To accomplish this mission, a 'Islamic Finance Research Unit' headed by a Professional Islamic Finance Researcher under Research Department may be established at Bangladesh Bank. The Department can perform several activities like (i) to collect data on Islamic finance and prepare monthly/quarterly and annual report; (ii) to conduct comprehensive research in various fields of Islamic Economics, finance and banking; (ii) to conduct field surveys on different Islamic Banking and finance issues and prepare papers/reports on the basis of data/information collected and surveys conducted.

x. Establishment of Modern Islamic Finance Academy: An IT based modern Islamic Finance Academy can be established for exploring full potentials of the Islamic finance. The academy can provide the theoretical and practical training programs to officials engaged in Islamic finance industry like regulators, supervisors and general Islamic bankers. The Academy can introduce short and long training courses ranging from certificate courses, Diploma, Graduate and $\mathrm{PhD}$ programs. The Academy can also conduct survey/research programs related to different problems and prospects of Islamic Finance in home and abroad. It can publish newsletters, bulletins and Journals regularly. The Academy can conduct 'Islamic Financial Literacy Program' across the country in establishing clear concepts and removing misconceptions relating to Islamic finance.

xi. Formation of Fund for Human Resources Development in Islamic Finance: It is urgent to setup a fund named 'Fund for Human Resources Development in Islamic Finance' to attract talent people in the Islamic finance industry. On the basis of the contribution of each Islamic bank according to the market share the fund is formed. The students who have interests in pursuing Diploma/MS/PhD in Islamic finance in home and abroad will be awarded scholarship from this funds. Half portion of the fund may be used for Islamic bankers who have already spent at least five years in the Islamic finance industry.

\section{Conclusion}

At present, comprehensive Islamic financial atmosphere exists in Bangladesh. However, the institutional infrastructure of Islamic finance should be further enhanced to ensure the effectiveness and competitiveness of this system. Information should be upgraded in each area so that investor's awareness of the exclusive features of Islamic financial system will be increased.

Islamic financial industry is considered one of the vital areas in the financial system of Bangladesh and this is the perfect time to introduce Islamic financial products so that it can be practiced by the citizen of Bangladesh. Islamic financial products should be based on Islamic shariah which can differentiate from conventional products.

In Bangladesh, various Islamic banking sector are operating their operation successfully. So the situation in Bangladesh for Islamic finance is different from other region in the world insofar, but the country has some weaknesses in specific Islamic finance regulations for which a comprehensive Islamic finance industry cannot be established. Most of the obstacles of the Islamic finance sector have been recognized and are to be addressed by the authorities. Furthermore, the huge potentiality of Islamic finance has already been recognized, and efforts are being made to create an environment so that the potentiality can bring into the reality. It would be in the interests of transparency, credibility and consistency to prepare an assessment of the status quo and to compile all intended actions and chosen strategies in an Islamic finance sector development plan.

Thus, Islamic finance is a rapidly growing part of the financial sector in the Islamic world. Now a days, Islamic finance is not only restricted within Islamic countries, but also it is scattering wherever there is a sizable Muslim community. Islamic Financial System should be followed by the philosophy of Islam and it is a part of the teachings of Islam itself.

\section{Reference}

Alam, M. N. (2000). Islamic banking in Bangladesh: A case study of IBBL. International Journal of Islamic Financial Services, 1(4).

Ali, S. N. (ed.). (2010). Islamic Finance: Innovation and Authenticity. Cambridge, MA. Islamic Finance Project. Islamic Legal Studies Program, Harvard Law School. 
Bangladesh Bank. (2016). Developments of Islamic Banking in Bangladesh, October-December, 2016, Research Department, Bangladesh.

Bangladesh Bank (2016). Financial Stability Report, 2016.

Bangladesh Bank-Scheduled Bank statistics, various issues.

Bhatty, A. (2007). Islamic Insurance: Trends, Opportunities and the Future of Takaful from the Growth and Global Market for Takaful by Sohail Jaffer (ed.), London: Euromoney, 3-21

Di Mauro, F., et. al. (2013). Islamic Finance in Europe, Occasional Paper Series, European Central Bank, No.146/ June 2013.

Ernst \& Young. (2013). The World Islamic Banking Competitiveness Report 2013 from http://www.ey.com/Publication/vwLUAssets/The_World_Islamic_Banking_Competitiveness_Report/\$FILE /World\%20Islamic\%20Banking\%20 Competitiveness\%20Report\%202012-13.pdf

Hussain, S. T. (2015). An Overview of Islamic Finance, IMF Working Paper African, European, and Middle East and Central Asia Departments.

IFSB. (2014). Prospects and Challenges in the Development of Islamic Finance in Bangladesh, IFSB, Malaysia.

Khorshid, A. (2004). Islamic Insurance: A Modern Approach to Islamic Banking, New York, Routledge. https://doi.org/10.4324/9780203458280

Mohamme, K. R. (2011). Re-Casting Development: Islamic Banking and the Case of the Islami Bank's Rural Development Scheme in Bangladesh. Journal of International Development, 23(6), 855-867. https://doi.org/10.1002/jid.1814

Muhammad, M. Z. (2011). Prospects and Problems of Islamic Banking from Bank's Perspective: A Study of Bangladesh. 8th International Conference on Islamic Economics and Finance, Doha, Qatar.

Smolo, E., \& Abdul, G. I. (2011). A Theory and Contractual Framework of Islamic Micro-financial Institutions' Operations. Journal of Financial Services Marketing, 15(4), 287-295. https://doi.org/10.1057/fsm.2010.24

Zahid, R., et al. (2011). Growth and Prospect of Islamic Finance in Malaysia, 2011 International Conference on Social Science and Humanity IPEDR vol.5 (2011) C (2011) IACSIT Press, Singapore.

Zulkifli, H. (2012). Shari'ah Governance in Islamic Banks. Edinburgh. Edinburgh University Press.

Alawode, A. (2013, May 30). Can Islamic Finance Spur Inclusive Growth \& Sustainable Development, from http://blogs.worldbank.org/psd/can-islamic-finance-spur-inclusive-growth-sustainable-development

\section{Abbreviations}

AAOIFI Accounting and Auditing Organization for Islamic Financial Institutions

IBBL Islamic Bank Bangladesh Limited

ICB Investment Corporation of Bangladesh

GCC Gulf Cooperation Council

HSBC Hongkong Sanghai Banking Corporation

CAGR Compound Annual Growth Rate

IFSB Islamic Financial Services Board

UAE United Arab Emirates

OIC Organization of Islamic Cooperation

MIFC Malaysia International Islamic Financial Center

PLS Profit and Loss Sharing

MSME Micro, Small and Medium Enterprises

UK United Kingdom

SEC Securities and Exchange Commission

\section{Copyrights}

Copyright for this article is retained by the author(s), with first publication rights granted to the journal.

This is an open-access article distributed under the terms and conditions of the Creative Commons Attribution license (http://creativecommons.org/licenses/by/4.0/). 